\title{
KONSEP HUBUNGAN KEWENANGAN ANTARA PEMERINTAH PUSAT DAN PEMERINTAH DAERAH DALAM BINGKAI NEGARA KESATUAN DENGAN CORAK OTONOMI LUAS
}

\author{
Oleh
Oleh: Wirazilmustaan, S.H*., MH., Rahmat Robuwan, S.H.,M.H**, Rio Armanda Agustian, S.H., M.H.***
Email: wira.aan@gmail.com

Abstract

\begin{abstract}
State of Indonesia is a very large country. It can be seen from many tribes, nations, cultures, languages, and others who are in Indonesia. As a unitary state with extensive autonomy, takes the concept of the relationship of authority between the central government and local governments. Administratively, the pattern of the relationship of authority between the central government and regional governments born of the delegation of authority. Who was born on the theory of delegation, supervision concept embraced by local governments in Indonesia are more inclined to form Hybrid variations (supervision), transfer of power from central to local government could be said to embrace open-end arrangement or general competence. therefore, a new paradigm in central and local relations should be established with the pattern of center-periphery relations towards a more harmonious, it's time developed progressive thinking that is based on relations that are complementary and interdependent.
\end{abstract}

Keyword :Unitary State, the Central Government and Local Government

\section{A. PENDAHULUAN}

Pasca reformasi terjadi perubahan yang sangat fundamental dalam pelaksanaan pemerintahan di Indonesia, termasuk pemerintahan daerah. Tuntutan reformasi yang menghendaki adanya desentralisasi dan hubungan yang adil antara pusat dan daerah (otonomi daerah) melahirkan pemikiran yang utuh dan selaras atas keinginan untuk menjadikan Negara Kesatuan Republik Indonesia menggunakan otonomi yang luas. Pada dasarnya konsep negara kesatuan dapat ditinjau dari segi susunanya, yakni memiliki susunan yang tunggal. Negara kesatuan adalah negara yang tidak tersusun dari beberapa negara, sehingga tidak ada negara dalam negara. ${ }^{1}$ Dalam hanya ada satu pemerintah, yaitu pemerintah pusat yang mempunyai kekuasaan serta 
wewenang tertinggi dalam bidang pemerintahan negara, menetapkan kebijaksanaan pemerintahan dan melaksanakan pemerintahan negara baik di pusat maupun di daerahdaerah.

Namun dengan adanya perkembangan yang sangat signifikan terkait urusan pemerintahan terutama di daerah ditambah lagi dengan masyarakat yang semakin heterogen, acap kali menimbulkan permasalahan yang kompleks. Oleh karena itu dalam perkembangan selanjutnya, banyak negara kesatuan memodifikasi administrasi pemerintahannya melaksanakan asas desentralisasi serta otonomi daerah.

Di Indonesia, terutama pasca reformasi, cita-cita untuk membentuk otonomi daerah yang sesungguhnya itu tidak hanya sekadar wacana belaka, pengaturan mengenai pemerintahan daerah diatur dalam bab tersendiri di dalam Undang-Undang Dasar Negara republik Indonesia Tahun 1945 (UUD NRI 1945), yakni pada Bab VI mencangkup 3 pasal, antara lain Pasal 18 yang terdiri dari 7 ayat di mana dalam ketentuan tersebut, antara lain ditegaskan bahwa pemerintah daerah (baik provinsi, kabupaten, maupun kota) mengatur dan mengurus sendiri urusan pemerintahan menurut asas otonomi dan tugas pembantuan.

Pasal 18A yang terdiri dari 2 ayat yang menegaskan mengenai hubungan kewenangan pemerintahan pusat dan daerah baik provinsi, kabupaten/ kota atau antara provinsi dan kabupaten dan kota serta hubungan keuangan antara pusat dan daerah, dan Pasal 18B terdiri dari 2 ayat mencantumkan mengenai negara yang mengakui dan menghormati pemerintahan yang berisifat khusus dan istimewa serta kesatuan-kesatuan masyarakat hukum adat beserta hak-hak tradisionalnya.

Dalam ketentuan UUD NRI 1945 pasca amandemen, ketentuan mengenai pemerintahan daerah diatur sendiri dalam Bab VI yang berjudul Pemerintahan Daerah. Dalam Pasal 18 ayat (1) dikatan :

"Negara Kesatuan Republik Indonesia dibagi atas daerahdaerah provinsi dan daerah provinsi itu dibagi atas kabupaten dan kota, yang tiap-tiap provinsi, kabupaten, dan kota itu mempunyai pemerintahan daerah, yang diatur dengan undang-undang".

Berdasarkan ketentuan di atas jelas bahwa konsep pembagian kekuasaan antara pemerintahan pusat dengan provinsi dan kabupaten/ kota ini bersifat pembagian yang bertingkattingkat (hierarkis). Dalam organisasi yang besar (dilihat dari berbagai 
dimensi) dan dianut paham demokrasi, selain sentralisasi dan dekonsentrasi, diselenggarakan pula asas desentralisasi. Dengan desentralisasi, terjadi pembentukan dan implementasi kebijakan yang tersebar di berbagai jenjang pemerintahan subnasional. Asas ini berfungsi untuk menciptakan keanekaragaman dalam penyelenggaraan pemerintahan, sesuai dengan kondisi dan potensi masyarakat. Dengan perkataan lain, desentralisasi berfungsi untuk mengakomodasi keanekaragaman masyarakat, sehingga terwujud variasi struktur dan politik untuk menyalurkan aspirasi masyarakat. ${ }^{2}$

Dalam penjabaran pasal tersebut, terutama pada Pasal 18, menjadi dasar hukum bagi seluruh pemerintahan daerah untuk dapat menjalankan roda pemerintahan (termasuk menetapkan peraturan daerah dan peraturan lainnya) secara lebih leluasa dan bebas serta sesuai dengan kebutuhan, kondisi, dan karakteristik daerah masing-masing, kecuali untuk urusan pemerintahan yang dinyatakan oleh undang-undang sebagai urusan pemerintah pusat. $^{3}$ Implikasi dari

2 Ni'matul Huda, Hukum Pemerintahan Daerah, Nusamedia, Bandung, 2009, hlm. 13.

3 MPR RI, Paduan Pemasyarakatan Undang-Undang Dasar Negara Republik Indonesia Tahun 1945, Sesuai Dengan Urutan perubahan yang sangat mendasar dalam tatanan pemerintahan daerah ini ialah munculnya tuntutan untuk evaluasi dan revisi terhadap berbagai perundang-undangan di bidang politik dan pemerintahan daerah. Awal reformasi tepatnya tanggal 7 Mei 1999 lahirnya undang-undang yang mengatur tentang pemerintahan daerah yakni Undang-Undang Nomor 22 Tahun 1999 tentang Pemerintahan Daerah. Namun dinamika yang berkembang dengan pelaksanaan undang-undang tersebut justru menimbulkan permasalahan yang sangat kompleks terkait pemerintahan di daerah. Kemudian prakarsa perubahan undang-undang pemerintahan daerah mulai bergulir yang kemudian undang-undang tersebut diubah dengan melahirkan Undang-Undang Nomor 32 Tahun 2004 tentang Pemerintahan Daerah yang disusul dengan kelahiran Undang-Undang Nomor 12 Tahun 2008 tentang Pemerintahan Daerah kemudian diubah lagi menjadi Undang-Undang Nomor 1 Tahun 2015 tentang Penetapan Peraturan Pemerintah Pengganti UndangUndang Nomor 1 Tahun 2014 tentang Pemilihan Gubernur, Bupati, dan

Bab, Pasal, dan Ayat, Seketariat Jenderal MPR RI, Jakarta, 2009, hlm. 80. 
Walikota Menjadi Undang-Undang yang menjadi jawaban dari kemelut tentang pemerintahan daerah akhir masa pemerintahan Presiden Susilo Bambang Yudhoyono (SBY).

Mengenai masalah otonomi daerah hingga saat ini pun masih menjadi topik yang diskusi yang menarik, karena setiap kali membahas masalah otonomi, yang muncul ke permukaan adalah spanning antara kepentingan pusat dan daerah, dan sejauh mana otonomi itu diberikan secara nyata kepada daerah. Selama ini tuntutan agar urusan pemerintahan sepenuhnya dilimpahkan kepada daerah otonom dalam penyelenggaraan pemerintahan daerah, oleh pemerintah baru direspon sebatas retorika. Sementara masalah yang timbul dari implikasi hubungan kewenangan baik antara pusatprovinsi dan provinsi-kabupaten/ kota maupun antara sektoral dan daerah ialah terdapat berbagai ketidakpastian dalam batas kewenangannya. Untuk itu perlu tinjauan secara normatif dengan menganalisis undang-undang terkait pemerintahan daerah yang terkini mengenai konsep hubungan kewenangan seperti apa yang baiknya diterapkan dalam menjalankan roda pemerintahan antara pusat dan daerah itu sesuai dengan bingkai konsep negara kesatuan yang dianut oleh negara Indonesia.

Dari latar belakang di atas dapat dibuat beberapa rumusan masalah yaitu;

1. Bagaimana hubungan kewenangan pemerintahan antara pemerintah daerah dan pemerintah pusat di Negara Kesatuan Republik Indonesia?

2. Teori apakah yang digunakan dalam hubungan kewenangan antara pemerintah daerah dan pemerintah pusat di Negara Kesatuan Republik Indonesia?

3. Bagaiamana bentuk pengendalian pemerintah pusat pada pemerintah daerah di Negara Kesatuan Republik Indonesia?

4. Bagaimana penyerahan wewenang pemerintah pusat kepada daerah Negara Kesatuan Republik Indonesia?

5. Bagaimana bentuk paradigma baru hubungan kewenangan antara pusat dan daerah di Negara Kesatuan Republik Indonesia?

\section{B. PEMBAHASAN}

\section{Hubungan Kewenangan Pusat}

\section{Daerah}

Menurut C.F. Strong negara kesatuan adalah bentuk negara dimana wewenang legislatif tertinggi di 
pusatnya dalam satu badan legislatif nasional/pusat. Pemerintah pusat mempunyai wewenang untuk menyerahkan sebagian kekuasaannya kepada daerah berdasarkan hak otonomi (negara kesatuan dengan sistem desentralisasi), tetapi pada tahap akhir kekuasaan tertinggi tetap di tangan pemerintah pusat. ${ }^{4}$ Adapun yang menjadi hakikat negara kesatuan adalah kedaulatannya tidak terbagi, atau dengan perkataan lain kekuasaan pemerintah pusat tidak dibatasi oleh karena konstitusi negara kesatuan tidak mengakui badan legislatif lain selain badan legislatif pusat. C.F Strong selanjutnya menyatakan bahwa ada dua ciri mutlak yang melekat padanegara kesatuan yakni;

1. Adanya supremasi dari Dewan Perwakilan Rakyat Pusat.

2. Tidak adanya badan-badan lainnya yang berdaulat.

Dalam menjalankan pemerintahan daerah haruslah dibentuk secara sistematis baik dari segi pola hubungannya dengan pemerintah pusat, kewenangannya, serta pengelolaannya dan lain-lain. Oleh karena itu menurut Prof. Soehino, sistem pemerintahan di daerah pada

${ }^{4}$ C.F Strong, Konstitusi-Konstitusi Politik Moder, Terjemahan, Nusa Media, Bandung, 2011, hlm. 111. prinsipnya harus menyesuaikan diri dengan sistem pemerintahan pusat, yang umumnya sistem tersebut telah ditegaskan dalam UUD. ${ }^{5}$ Dengan pandangan tersebut jelas bahwasannya dalam pola negara kesatuan sesungguhnya pemerintahan daerah harus tetap memiliki korelasi yang selaras dengan berdasarkan pada hubungan vertikal dan horizontal antara pemerintah pusat dan daerah yang tersusun dengan jiwa negara kesatuan, karena sekali lagi negara kesatuan berbeda dengan negara federal atau negara serikat.

Pengaturan mengenai otonomi daerah yang pasca reformasi undangundang telah berganti-ganti mulai dari Undang-Undang Nomor 22 Tahun 1999 tentang Pemerintahan Daerah, Undang-Undang Nomor 32 Tahun 2004 tentang Pemerintahan Daerah, dan Undang-Undang Nomor 23 Tahun 2014 tentang Pemerintahan Daerah yang kemudian diubah Peraturan Pemerintah Pengganti UndangUndang Nomor 1 Tahun 2014 tentang Pemilihan Gubernur, Bupati, dan Walikota dan ditetapkan dengan Undang-Undang Republik Indonesia Nomor 1 Tahun 2015 tentang Penetapan Peraturan Pemerintah

5 Soehino, Perkembangan Pemerintahan di Daerah, Liberty, Yogyakarta, 1983, hlm. 1. 
Pengganti Undang-Undang Nomor 1

Tahun 2014 tentang Pemilihan

Gubernur, Bupati, dan Walikota

Menjadi Undang-Undang

Namun yang perlu diingat bahwasannya muaranya ialah dari ketentuan undang-undang pemerintahan daerah tersebut ialah sama, yakni to bring the government close to the people (membawa pemerintah lebih dekat dengan rakyat) sehingga pemerintah lebih menghayati bahwa ia ada karena dibutuhkan rakyatnya dan ia merupakan bagian dari rakyat. ${ }^{6}$

Telaah mengenai konsep hubungan kewenangan antara pemerintahan pusat dan pemerintahan daerah ini sesungguhnya memiliki cakupan yang sangat luas. Dari perspektif teori mengenai desentralisasi dan otonomi daerah memiliki definisi yang tidak tunggal, namun begitu banyak definisi yang dikemukakan oleh para pakar mengenai desentralisasi. Kemudian dengan menjabarkan dari berbagai perspektif teori, ada dua definisi tentang desentralisasi, yakni definisi dari perspektif administrasi dan perspektif politik. Dalam perspektif administrasi, desentralisasi itu tidak

6 Lembaga Administrasi Negara, Manajemen Pemerintahan Daerah, Lembaga Administrasi Negara, Jakarta, 2008, hlm. 59. jauh beda dengan dekosentrasi ini yang kemukakan oleh Parson yang menegaskan bahwa desentralisasi didefinisikan sebagai the transfer of administerative responbility from central to local governance. Bandingkan dengan kosep dekonsentrasi yang dibangun oleh Parson yakni sharing of power between members of the same ruling group having aouthority respectively in defferent areas of the state. ${ }^{7}$

Melihat dari undang-undang pemerintahan daerah definisi tentang desentralisasi dan dekonsentrasi yakni dimuat dalam Pasal 1 angka 8 dan 9 Undang-Undang Nomor 23 Tahun 2014 tentang Pemerintahan Daerah yakni desentralisasi adalah penyerahan urusan pemerintahanvoleh pemerintah pusat kepada daerah otonom berdasarkan asas otonomi. Sedangkan dekonsentrasi adalah pelimpahan sebagian urusan pemerintahan yang menjadi kewenangan pemerintah pusat kepada gubernur sebagai wakil pemerintah pusat, kepada instansi vertikal di wilayah tertentu, dan/atau kepada gubernur dan bupati/wali kota

${ }^{7}$ Lili Romli, Potret Otonomi Daerah dan Wakil Rakyat di Tingkat Lokal, Pustaka Pelajar, Yogyakarta, 2007, hlm. 4. 
sebagai penanggung jawab urusan pemerintahan umum. ${ }^{8}$

Sementara itu dalam perspektif politik, Smith mengatakan bahwa desentralisasi adalah the transfer of power, from top level to lower level in a territorial hierarchy, which could be one of governance within a state, or offices within a large organization. ${ }^{9}$ Dari penjelasan diatas dapat ditarik kesimpulan bahwa pemaknaan mengenai desentralisasi ini dapat dibedakan dalam dua perspektif, yakni perspektif desentralisasi politik yang mendefinisikan desentralisasi sebagai devolusi kekuasaan, devolutionof power, dari pemerintahan pusat kepada pemerintahan daerah. Sedangkan perspektif desentralisasi administrasi mendefinisikan desentralisasi sebagai delegasi wewenang adminitratif, dari pemerintahan pusat kepada pemerintahan daerah.

Secara administratif dapat kita lihat bahwa pola hubungan kewenangan antara pemerintahan pusat dan pemerintahan daerah dilahirkan dari pendelegasian kewenangan. Senada dengan hal tersebut, Shabir Cheeman dan Rondinelli menyampaikan 14

\footnotetext{
${ }^{8}$ Lihat UU No 23 Tahun 2014 Pasal 1 angka 8 dan 9 . hlm. 5 .
}

alasan yang merupakan rasionalitas dari desentralisasi yang salah satunya ialah bahwa desentralisasi dapat merupakan cara yang ditempuh untuk mengatasi keterbatasan karena perencanaan yang bersifat sentralistik dengan mendelegasikan sejumlah kewenangan, terutama dalam perencanaan pembangunan, kepada pejabat di daerah yang bekerja di lapangan dan tahu betul masalah yang dihadapi masyarakat. ${ }^{10}$

Bagir Manan menjelaskan bahwa hubungan pusat dan daerah dalam kerangka desentralisasi tersebut berdasarkan hal-hal berikut antara lain: ${ }^{11}$

1. Permusyawaratan dalam sistem pemerintahan negara;

2. Pemeliharaan dan pengembangan prinsip-prinsi pemerintahan asli;

3. Kebhinekaan; dan

4. Negara hukum.

\section{Teori Lahirnya Kewenangan}

\section{Pemerintah Daerah}

Untuk lebih memahami mengenai teori mengenai sumber dan cara memperoleh kewenangan, dalam khasanah ilmu hukum dikenal 3 cara

10 Syaukani DKK, Otonomi Daerah Dalam Negara Kesatuan, Pustaka Pelajar, 2007, hlm. 33 .

11 Bagir Manan, Hubungan Antara Pusat dan Daerah Menurut UUD 1945, Pustaka SInar Harapan, Jakarta, 1994, hlm. 161. 
untuk memperoleh kewenangan, yakni antara lain:

1. Atribusi

Menurut Indroharto, atribusi adalah pemberian wewenang pemerintah yang baru oleh suatu ketentuan dalam perundangundangan baik yang dilakukan oleh original legislator ataupun delegated legislator. ${ }^{12}$ Atribusi dalam Undang-Undang Nomor 30 Tahun 2014 tentang Pemerintahan Daerah Pasal 1 angka 22 adalah pemberian kewenangan kepada badan dan/atau pejabat pemerintahan oleh Undang-Undang Dasar Negara Republik Indonesia Tahun 1945 atau Undang-Undang.

2. Delegasi

Menurut HD. Van Wijk, delegasi adalah penyerahan wewenang pemerintah dari suatu badan atau pejabat pemerintahan kepada badan atau pejabat pemerintahan lain. Selanjutnya van Wijk menjelaskan lebih lanjut, bahwa wewenang yang didapat dari didelegasikan lagi kepada subdelegetaris. ${ }^{13}$ Delegasi adalah pelimpahan kewenangan dari badan

12 Juniarso Ridwan DKK, Hukum Administrasi Negara dan Kebijakan Pelayanan Publik, Nuansa Cendikia, Bandung 2012, hlm. 138.

${ }^{13}$ Ibid. dan/atau pejabat pemerintahan yang lebih tinggi kepada badan dan/atau pejabat pemerintahan yang lebih rendah dengan tanggung jawab dan tanggung gugat beralih sepenuhnya kepada penerima delegasi.

Dalam hal pelimpahan wewenang pemerintahan melalui delegasi tersebut terdapat syaratsyarat sebagai berikut: ${ }^{14}$

a. Delegasi harus definitif dan pemberi delegasi tidak dapat lagi menggunakan sendiri wewenang yang telah dilimpahkan;

b. Delegasi harus berdasarkan ketentuan peraturan perundangundangan, artinya delegasi hanya dimungkinkan kalau ada ketentuan untuk itu dalam peraturan perundang-undangan;

c. Delegasi tidak kepada bawahan, artinya dalam hubungan hierarki kepegawaian tidak diperkenankan dengan delegasi;

1) Kewajiban memberikan keterangan (penjelasan), artinya delegasi berwenang untuk meminta penjelasan tentang pelaksanaan wewenang tersebut;

2) Peraturan kebijakan, artinya delegan memberikan instruksi 
Jurnal Hukum Progresif: Volume XII/No.2/ Desember 2018 Wirazilmustaan, dkk. : Konsep...

(petunjuk) tentang
penggunaan wewenang
tersebut.

3. Mandat

Wewenang melalui yang didapat melalui atribusi dan delegasi bisa dimandatkan kepada badan atau pegawai bawahan jika pejabat yang memperoleh wewenang itu tidak sanggup untuk melakukan sendiri.

HD van Wijk menjelaskan arti mandat adalah suatu organ pemerintahan mengizinkan kewenangannya dijalankan oleh organ lain atas namanya. ${ }^{15}$ Pasal 1 angka 24, mendefinisikan mandat sebagai pelimpahan kewenangan dari badan dan/atau pejabat pemerintahan yang lebih tinggi kepada badan dan/atau pejabat pemerintahan yang lebih rendah dengan tanggung jawab dan tanggung gugat tetap berada pada pemberi mandat.

Jika mengkaji dalam undangundangan tentang pemerintahan daerah, pada dasarnya kewenangan pemerintahan daerah bisa dikatakan lahir teori delegasi. Karena pada dasarnya meskipun dalam undangundang tersebut ada beberapa kewenangan yang secara langsung

${ }^{15}$ Ibid. diberikan dari undang-undang kepada kepala daerah, namun pada dasarnya kewenangan tersebut merupakan perpanjangan kekuasaan dari pemerintah pusat. Pemerintah daerah tidak dapat serta merta menjalankan kewenangannya dalam menjalankan roda pemerintah daerah, oleh karena itu baik dalam menyusun peraturan daerah maupun bentuk administratif lain di daerah tetap harus dijalankan berdasarkan koridor yang telah ditetapkan oleh pusat, dengan kata lain bingkai negara kesatuan tetap harus dikukuhkan dalam pemerintahan daerah.

\section{Bentuk Pengendalaian Hubungan}

\section{Kewenangan Pusat dan Daerah}

Penjabaran di atas telah menjawab satu permasalahan bahwasannya lahirnya kewenangan pemerintahan daerah ialah melalui pendelegasian. Kemudian yang menjadi pembahasan berikutnya ialah bagaimana bentuk pengendaliannya. Berdasarkan teori dan praktik pemerintahan daerah setidaknya ada 4 variasi pengendalian penyelenggaraan urusan-urusan pemerintahan yang bersifat lokal, yakni antara lain $:^{16}$

16 Hanif Nurcholis, Teori dan Praktik Pemerintahan dan Otonomi Daerah, Grasindo, Jakarta, 2005, hlm. 74. 
1. Organisasi Internal (InternalOrganization/Regulation)

Dalam sistem ini kepala daerah bertanggungjawab penuh kepada Dewan Perwakilan Daerah (DPD). Contohnya, pemerintahan daerah di Inggris

2. Hybrid (Subsidiarization)

Dalam sistem ini kepala daerah bertanggungjawab kepada DPD untuk urusan-urusan yang sangat penting tapi juga bertanggungjawab kepada otoritas yang lebih tinggi untuk urusan-urusan spesifik yang merupakan kebijakan pusat. Contohnya, pemerintah daerah di Republik Federal Jerman

\section{Hybrid (supervision)}

Dalam sistem ini kepala daerah bertanggungjawab sebagian kepada DPD, dan sebagian wakil pemerintah pusat atau anggota dari agen kementerian pusat, bertanggungjawab secara langsung kepada otoritas yang mesupervisinya. Contohnya, pemerintahan loKal Perancis

4. Antar Organisasi (Intraorganization/subordinazation)

Dalam sistem ini kepala daerah adalah bagian dari hierarki pusat dan secara keseluruhan merupakan bawahan pusat. Contohnya, pemerintahan lokal Uni Soviet.
Konsep pengawasan yang dianut oleh pemerintah daerah di Indonesia lebih condong kepada bentuk variasi Hybrid (supervision). Hal ini dapat dikaji di dalam undang-undang pemerintahan daerah yang menegaskan bahwa gubernur sebagai kepala daerah provinsi juga sebagai wakil pemerintah pusat di daerah. Kemudian urusan pengawasan pemerintahan pusat kepada daerah dibentuk secara vertikal, untuk pemerintah daerah provinsi diawasi langsung oleh menteri dalam negeri dan kepala/ lembaga lembaga nonkemeterian, sedangkan untuk pemerintah daerah kabupaten/ kota dilaksanakan oleh gubernur sebagai wakil pemerintah pusat di daerah. ${ }^{17}$ Namun perlu diingat tanggungjawab akhir atas penyelenggaraan pemerintahan tetap berada di presiden. Esensi inilah yang kemudian membangun suatu pemerintahan daerah yang tetap pada koridor negara kesatuan dengan bentuk pendelegasian kewenangan.

\section{Penyerahan Wewenang Pemerintah Pusat Kepada Daerah}

Kemudian mengenai cara penyerahan wewenang pemerintahan

\footnotetext{
${ }^{17}$ Lihat Pasal 8 UU No 23 Tahun 2014 tentang Pemerintahan Daerah
} 
oleh pemerintah pusat kepada daerah, ternyata dalam mengkaji literatur, ditemukan dua cara penyerahan wewenang pemerintahan dari pusat ke daerah, yakni antara lain :

1. Ultra vires doctrine, yaitu pemerintah pusat yang menyerahkan wewenang pemerintahan kepada daerah otonom dengan cara merinci satu per satu. Daerah otonom hanya boleh menyelenggarakan wewenang yang diserahkan tersebut. Sisa wewenang dari wewenang yang diserahkan kepada daerah otonom secara terperinci tersebut tetap menjadi wewenang pusat.

2. Open end arrangement atau general competence, yaitu daerah otonom boleh menyelenggarakan semua urusan di luar yang dimiliki pusat. Artinya, pusat menyerahkan kewenangan pemerintahan kepada daerah untuk menyelenggarakan kewenangan berdasarkan kebutuhan dan inisiatifnya sendiri di luar kewenangan yang dimiliki pusat.

Dalam Undang-Undang Nomor 23

Tahun 2004 tentang Pemerintahan Daerah mengenai urusan pemerintahan dibagi menjadi 3, yakni urusan pemerintahan absolut, urusan pemerintahan konkuren, dan urusan pemerintahan umum. Urusan pemerintahan absolut adalah urusan yang sepenuhnya menjadi kewenangan pemerintah pusat, urusan pemerintahan konkuren adalah urusan pemerintahan yang dibagi antara pemerintah pusat dan daerah provinsi dan daerah kabupaten/ kota yang selanjutnya penyerahan urusan tersebut menjadi dasar pelaksanaan otonomi daerah, sedangkan urusan pemerintahan umum adalah urusan pemerintahan yang menjadi kewenangan presiden sebagai kepala pemerintahan.

Melihat dari ketentuan UndangUndang Nomor 23 Tahun 2014 tentang Pemerintahan Daerah, penyerahan wewenang dari pemerintah pusat ke daerah bisa dikatakan menganut open end arrangement atau general competence. Meskipun urusan tersebut telah dibagi dalam tiga bentuk, namun pada prinsipnya kewenangan yang diberikan oleh pusat dan daerah ialah seluruh kewenangan kecuali yang termaktub dalam urusan pemerintahan absolut. Pengaturan selanjutnya menegaskan adanya urusan wajib dan pilihan dalam urusan pemerintahan konkuren tersebut, artinya meskipun menjadi kewenangan pemerintahan 
daerah namun adakalanya hal tersebut menjadi kewajiban pemerintahan daerah untuk melaksanakannya adapula yang menjadi pilihan (choice) bagi pemerintahan daerah. Sebagaimana dimaksud dalam undang-undang bahwasannya pembagian urusan konkuren ini memiliki dasar yakni prinsip akuntabilitas, efisiensi, dan eksternalitas, serta kepentingan strategis nasional.

\section{Paradigma Baru Hubungan}

Kewenangan Antara Pusat dan Daerah

Pemerintah daerah untuk mengatur dan mengurus bagian-bagian tertentu urusan pemerintahan. Sesuai UUD NRI 1945, karena Indonesia adalah "eenheidstaat", maka di dalam lingkungannya tidak dimungkinkan adanya daerah yang bersifaat staat juga ini berarti bahwa sebagian pembatas besar dan luasnya daerah otonom dan hubungan kekuasaan antara pemerintah pusat dan daerah adalah menghindari daerah otonom menjadi negara dalam negara. Dengan demikian jelaslah bahwa desentralisasi merupakan instrumen dicapainya tujuan bernegara dalam kerangka kesatuan bangsa (national unity) yang demokratis (democratic government).
Dalam konteks UUD NRI 1945, selalu harus diperhatikan keseimbangan antara kebutuhan untuk menyelenggarakan desentralisasi dengan kebutuhan memperkuat kesatuan nasional.

Dalam konteks relasi pusat-daerah, cara pandangan sentralistik yang cenderung hierarkis-dominatif dan melihat daerah sebagai sub-ordinasi pusat, sudah tentu tidak sesuai lagi dengan tuntutan reformasi dan demokratisasi. Resistensi daerah terhadap pusat pada dasarnya bersumber dari kecenderungan cara pandang hierarkis-dominatif, sehingga tidak ada peluang bagi daerah untuk berkembang sesuai kemampuan, potensi, dan keanekaragaman masingmasing daerah.

Dalam rangka penataan kembali hubungan pusat-daerah ke arah yang lebih harmonis, sudah waktunya dikembangkan pemikiran yang progresif yang didasarkan pada relasi yang bersifat komplementer dan interpenden. Artinya, meskipun secara hierarki pemerintah daerah berkedudukan lebih rendah, tetapi pengaturan hubungan pusat-daerah meniscayakan berlakunya asas kemitraan dan saling tergantung di antara keduanya, apalagi bila mengingat sifat komunitas-komunitas 
lokal yang pada dasarnya memang telah memiliki otonomi sebelumnya. Konsekuensi logis dari pemikiran ini adalah keperluan berlakunya cara pandang otonomi daerah sebagai "kontrak" antara pemerintah pusat dan pemerintah daerah melalui wakilwakil rakyat daerah. Cara pandang baru ini diharapkan bukan hanya bisa menjamin hubungan yang bersifat kemitraan dan kesaling-tergantungan antara pusat-daerah melainkan juga dapat menjadi dasar bagi hubungan yang lebih harmonis di antara kedua pihak di masa depan.

\section{KESIMPULAN}

Permasalahan mengenai hubungan kewenangan pusat dan daerah dalam otonomi sesungguhnya menjadi pembahasan yang sangat menarik. Kita ketahui bahwasannya hubungan kewenangan pusat dan daerah itu sendiri dalam perkembangannya selalu berubah. Hal tersebut seiring dengan keinginan untuk mensinkronisasi bentuk ideal pemerintahan suatu negara kesatuan yang didesentralisasikan agar tidak lepas dari makna atau intisari dari negara kesatuan itu sendiri.

Sebagai negara yang sangat luas tentunya Indonesia sebagai negara kesatuan memiliki berbagai dimensi permasalahan, hal ini dikarenakan perbedaan di berbagai aspek baik budaya, politik, ekonomi, sosial, dan lainya di tiap-tiap daerah di Indoensia. Oleh karena itu, dalam menjalin hubugan kewenangan antara pusat dan daerah perlu untuk menentukan bahwasannya kewenangan yang di desentralisasikan kepada daerah tersebut lahir melalui teori apa. Ternyata dapat ditemukan bahwa teori lahirnya kewenangan daerah tersebut ialah melalui teori delegasi yakni penyerahan wewenang pemerintah dari suatu badan atau pejabat pemerintahan kepada badan atau pejabat pemerintahan lain. Di sini penyerahan wewenang tersebut terjadi dari pemerintah pusat kepada pemerintah daerah, meskipun dalam undang-undang sendiri ada wewenang yang ditentukan oleh undang-undang sebagai wewenang pemerintah daerah namun sesungguhnya wewenang tersebut merupakan turunan wewenang dari pemerintah pusat, hal ini sejalan dengan teori negara kesatuan yang menurut Ni'matul Huda pusat dan daerah itu dibentuk menyerupai hierarki pemerintahan.

Untuk pengawasan hubungan pusat dan daerah yakni menggunakan variasi Hybrid (supervision). Ini sejalan dengan koridor negara 
kesatuan yang hierarki di mana pemerintah daerah yang dibentuk bertingkat-tingkat (pemerintah daerah provinsi dan pemerintah daerah kabupaten/ kota) harus memiliki korelasi. Pengawas utama tetap berada di tangan pemerintah pusat. Presiden memiliki peran sentral yang utama dalam usaha untuk mengawasi alur pemerintahan di daerah karena sesuai dengan statusnya sebagai kepala pemerintahan.

Sedangkan mengenai penyerahan kewenangan, dengan mulai dari Undang-Undang Nomor 22 Tahun 1999 tentang Pemerintahan Daerah hingga Undang-Undang Nomor 1 Tahun 2015 tentang Penetapan Peraturan Pemerintah Pengganti Undang-Undang Nomor 1 Tahun 2014 tentang Pemilihan Gubernur, Bupati, dan Walikota Menjadi UndangUndang meskipun memiliki perbedaan dalam pengaturan mengenai wewenang pemerintahan daerah namun tetap dalam koridor bentuk teori open end arrangement atau general competence. Karena ada kewenangan-kewenangan atau urusanurusan tertentu yang telah dicantumkan dalam undang-undang bahwa sebagai urusan pemerintah pusat yang mana pemerintah daerah tidak memiliki kewenangan untuk melakukan urusan tersebut.

Sehingga melalui karakter utama dalam menyoroti aspek hubungan pusat dan daerah ditemukan suatu pemikiran untuk membangun paradigma baru dalam hubungan pusat dan daerah di mana pola hubungan pusat-daerah sudah seharusnya dibentuk kearah yang lebih harmonis, sudah waktunya dikembangkan pemikiran yang progresif yang didasarkan pada relasi yang bersifat komplementer dan interdependen. Resistensi daerah terhadap pusat pada yang dasarnya bersumber dari kecenderungan cara pandang hierarkis-dominatif harus diubah sehingga daerah berpeluang untuk berkembang sesuai kemampuan, potensi, dan keanekaragaman masingmasing daerah.

\section{DAFTAR PUSTAKA}

\section{Buku-Buku}

Bagir Manan, 1994, Hubungan Antara Pusat dan Daerah Menurut UUD 1945, Pustaka Sinar Harapan, Jakarta.

C.F Strong, 2011, KonstitusiKonstitusi Politik Modern, Terjemahan, Nusa Media, Bandung.

Hanif Nurcholis, 2005, Teori dan Praktik Pemerintahan dan 
Otonomi Daerah, Grasindo, Jakarta.

Juniarso Ridwan dkk., 2012, Hukum Administrasi Negara dan Kebijakan Pelayanan Publik, Nuansa Cendikia, Bandung .

Lembaga Administrasi Negara, 2008, Manajemen Pemerintahan Daerah, Lembaga Administrasi Negara, Jakarta.

Lili Romli, 2007, Potret Otonomi Daerah dan Wakil Rakyat di Tingkat Lokal, Pustaka Pelajar, Yogyakarta.

MPR RI, 2009, Paduan Pemasyarakatan UndangUndang Dasar Negara Republik Indonesia Tahun 1945, Sesuai Dengan Urutan Bab, Pasal, dan Ayat, Seketariat Jenderal MPR RI, Jakarta.

Ni'matul Huda, 2009, Hukum Pemerintahan Daerah, Nusamedia, Bandung.

Philipus M Hadjon dkk, 2005, ,Pengantar Hukum Administrasi Indonesia, Gajah Mada University Press, Yogyakarta.

Soehino, 2005, Ilmu Negara, Liberty, Yogyakarta.

\section{3, Perkembangan Pemerintahan di Daerah, Liberty, Yogyakarta.}

Syaukani dkk., 2007, Otonomi Daerah Dalam Negara Kesatuan, Pustaka Pelajar, Yogyakarta.

\section{Perundang-Undangan}

Undang-Undang Dasar Negara Republik Indonesia Tahun 1945.
Undang-Undang Republik Indonesia Nomor 2 Tahun 1999 tentang Pemerintahan Daerah.

Undang-Undang Republik Indonesia Nomor 32 Tahun 2004 tentang Pemerintahan Daerah.

Undang-Undang Republik Indonesia Nomor 12 Tahun 2008 tentang Pemerintahan Daerah.

Undang-Undang Republik Indonesia Nomor 23 tahun 2014 tentang Pemerintahan Daerah.

Undang-Undang Republik Indonesia Nomor 30 Tahun 2014 tentang Administrasi Pemerintahan.

Undang-Undang Republik Indonesia Nomor 1 Tahun 2015 tentang Penetapan Peraturan Pemerintah Pengganti Undang-Undang Nomor 1 Tahun 2014 tentang Pemilihan Gubernur, Bupati, dan Walikota Menjadi UndangUndang 